\title{
Asymmetric monetary \\ and exchange-rate policies \\ in Latin American countries \\ that use inflation targeting
}

\author{
Emiliano Libman
}

\begin{abstract}
In recent decades, Latin American countries have adopted more flexible exchange-rate regimes and set inflation targets. Several authors argue that some countries' monetary and exchange-rate policies suffer from a procyclical bias, whereby central banks are reluctant to reduce interest rates when inflation falls, but are willing to increase them when inflation edges up. Therefore, the exchange rate tends to appreciate a lot and depreciate little. This paper analyses the asymmetry of the monetary and exchangerate policies of the five largest Latin American countries in which inflation targets are used: Brazil, Chile, Colombia, Mexico and Peru. Nonlinear econometric techniques are used to show that there is "fear of floating", except possibly in Chile and Peru, and that the symptoms are more pronounced in Brazil and Mexico.
\end{abstract}

\section{Keywords}

Monetary policy, foreign exchange rates, inflation, econometric models, case studies, Latin America, Brazil, Chile, Colombia, Mexico, Peru

JEL classification

E58, F30, F43

\section{Author}

Emiliano Libman is a Research Fellow at the Macroeconomic Research for Development Centre ( $\mathrm{CIMaD}$ ) and Professor of Advanced Macroeconomics in the School of Economics and Business at Universidad Nacional de San Martín, Argentina. Email: emilianolibman@gmail.com. 


\section{Introduction}

In recent decades, several developed and non-developed countries have adopted inflation-targeting policy regimes, under which the central bank commits to delivering a low and stable rate of inflation, using a short-term interest rate as the main policy instrument. Inflation-targeting countries maintain a relatively open capital account, and the usual prescription is to let the exchange rate float freely and to refrain from foreign-exchange-market intervention.

As monetary policy is used to target inflation (and possibly also the output gap), interest-rate changes may put too much pressure on the foreign-exchange market; and most central banks are unwilling to tolerate very large exchange-rate fluctuations. Interventions to suppress exchange-rate volatility are often the norm. In fact, theory does not necessarily preclude the central bank from buying and selling foreign assets, as long as this policy aims to cushion temporary shocks or other exchangerate movements that are not justified by economic fundamentals.

The largest Latin American countries have all adopted inflation targeting, including Brazil (1999), Chile (1991), ${ }^{1}$ Colombia (1999), Mexico (2001) and Peru (2002). Although current exchange-rate regimes are much more flexible than in the past, central banks continue to intervene heavily in the foreign-exchange market to cushion wide exchange-rate swings (Chang, 2008).

There are good reasons to believe that this type of intervention has not been implemented with equal intensity during appreciation and depreciation episodes. For example, authors such as Barbosa-Filho (2015) and Ros (2015) argue that the central banks of Brazil and Mexico have conducted an "asymmetric monetary policy", in which they tighten too much when the economy is booming, and not loosening enough when deflationary pressures arise. As these countries' balance of payments capital accounts were extremely open, the implied interest-rate changes triggered exchange-rate movements that had a downward bias. ${ }^{2}$

Asymmetric behaviour can have implications for macroeconomic stability. For example, depending on whether shocks are positive or negative, the economy may adjust inadequately. A negative shock, such as a fall in the terms of trade, which requires a rise in the real exchange rate (a higher relative price for tradable goods) may be impossible if non-tradable goods prices are "sticky" and if the central bank is willing to counteract depreciations. But if the shock is positive, for example, if the terms of trade improve and an appreciation is called for, then the economy may adjust smoothly.

Alternatively, the presence of asymmetries may be a sign of underlying problems: for example, the literature on fear of floating posits that inflation is the underlying reason why central banks dislike depreciations. If inflation-targeting countries display fear of floating then there are good reasons to believe that inflation expectations are not well anchored by monetary policy.

In short, asymmetric behaviour has consequences for macroeconomic performance and is related to several sources of instability. It is therefore interesting to analyse whether the Latin American countries that have adopted flexible exchange-rate regimes fear exchange-rate fluctuations. This paper's contribution is to explore this asymmetry in monetary and exchange-rate policies in the main Latin American inflation-targeting countries. Nonlinear econometric techniques are used to test whether these countries' central banks were more willing to tolerate appreciations than depreciations, over the period 1999-2015, using daily data. Specifically, the observed behaviour of the exchange rate is analysed to identify the presence of any asymmetries. Nonetheless, exchange rates may behave

\footnotetext{
1 Although Chile adopted inflation targeting in 1991, but it only really started to float more or less freely in 1999 . This is not a problem as the estimates used in this study start in 1999, the period that combines inflation targeting and floating.

2 This paper abides by the convention of defining the exchange rate as the number of units of domestic currency per dollar; so, a fall in the exchange rate represents an appreciation, while a rise signifies a depreciation.
} 
asymmetrically for non-policy reasons; so, a set of central bank reaction functions for interest rates and reserve accumulation is also estimated, to determine the impact of monetary and exchange-rate policy on the observed behaviour of the exchange rate.

The paper's results can be summarized as follows. In Brazil and Mexico, exchange-rate changes seem to be anchored to an asymmetric band in which the lower bound is further from the target rate than the upper bound. Appreciations were more persistent than depreciations in all of the countries, except Peru, where both appreciations and depreciations were relatively short-lived (in other words, an appreciating exchange rate would soon be followed by a depreciation, and vice-versa). Appreciations were also a highly persistent phenomena in Brazil, Chile and Mexico. Lastly, in all cases except Chile, reserve accumulation seems to react to exchange-rate depreciations, but not to appreciations, and interest rates show little sensitivity to exchange-rate fluctuations. The overall picture thus suggests that "fear of depreciation" was most likely the norm in Brazil and Mexico; the Chilean central bank seems to operate the most flexible exchange-rate regime of the five; while the overall picture for Colombia and Peru is mixed.

The rest of this paper is structured as follows: section II contains a literature review; section III describes the econometric techniques used and presents the results, and section IV concludes.

\section{Literature review}

Recent macroeconomic thinking has converged on a synthesis, known as the "new consensus macroeconomics", which agrees on the desirability of an autonomous monetary policy and on how to conduct it. The interest rate has replaced monetary-policy rules based on the quantity of money. It has been shown that a model with explicit microfoundations based on a representative agent framework can determine the equilibrium without any reference to the quantity of money, provided the interest-rate rule is sufficiently sensitive to changes in the inflation rate.

This is known as the "Taylor principle", which, intuitively, states that the interest rate should be increased by more than inflation when inflation rises above target, to avoid an inflationary spiral, lower real interest rates and higher aggregate demand. Conversely, when inflation falls below the target, the interest rate should be reduced by more than inflation.

When the Taylor principle is satisfied, inflationary expectations are anchored by the inflation target. Moreover, if there are no real frictions, stabilizing inflation also implies stabilizing the output gap. This is the divine coincidence evoked by Blanchard and Gali (2007). Because inflation targeting appears to stabilize both output and inflation at very little cost, it has become the most popular and appealing macroeconomic regime. ${ }^{3}$

It is often claimed that the process should operate in a similar way for an open economy. The core propositions for a closed economy presumably also apply, although there are additional complications associated with the existence of external monetary and real shocks. Nonetheless, the effects of exchange-rate fluctuations and the scope of central-bank interventions in the foreign exchange market are subject to intense debate. While some authors argue that inflation targeting requires a fully flexible exchange rate, others are willing to accept a role for temporary interventions by the central bank (see Ball, 1999, for a discussion of these issues).

The largest Latin American countries have all adopted inflation targeting, including Brazil, Chile, Colombia, Mexico and Peru. Although exchange-rate regimes are much more flexible than in the past, central banks still intervene heavily to cushion large movements in exchange rates (Chang, 2008).

3 See Bernanke and Mishkin (1997) for a more precise description of inflation targeting. 
There are good reasons to believe that such interventions have not been implemented with the same intensity during episodes of appreciation and depreciation. Calvo and Reinhart (2002) argue that, when the financial system is highly dollarized, the central bank may fear that currency depreciations will trigger bank failures. It is also possible that central banks fear the inflationary effects of depreciations, although exchange-rate pass-through has recently declined by non-trivial amounts. This aversion to depreciation is often called "fear of floating".

On the other hand, when the competitiveness of the tradable sector is an issue, the central bank may intervene to prevent currency appreciations, a phenomenon known as a fear of appreciation, or the opposite of fear of floating, as exemplified by recent events in East Asia (Levy-Yeyati and Sturzenegger, 2007).

Some observers of the Latin American economies claim that inflation targeting has introduced a bias towards overvaluation, since central banks react more aggressively to curb depreciations, but are more cautiously when responding to appreciations (Barbosa-Filho, 2015; ${ }^{4}$ and Ros, 2015). ${ }^{5}$ Unlike the East Asian countries that intervened in the foreign-exchange market to suppress appreciations (Pontines and Rajan, 2011; Pontines and Siregar, 2012), some Latin American countries seem to intervene in the opposite direction.

This paper will analyse the behaviour of exchange rates in the main Latin American countries that have used inflation targeting over the last 15 years. A panel smooth transition autoregressive model with three regimes is estimated, along with a Markov-switching model. These two models will estimate the upper and lower bounds of an exchange rate band, and the probabilities of a transition from depreciation to appreciation, respectively, for a series consisting of the natural logarithm of the rate of variation of the exchange rate. This is the simplest way to test whether monetary and exchange-rate policy in inflation-targeting Latin American countries was in fact asymmetric; and it follows the approach suggested by Pontines and Siregar (2012).

As exchange rates may also be affected by non-policy factors, Pontines and Siregar's approach is extended by estimating a set of reaction functions for the benchmark interest rate and reserve accumulation, to analyse the role of policy in shaping exchange-rate behaviour. This will provide a more precise answer to the question of whether fear of floating or fear of depreciation (or neither) was the overriding concern among inflation-targeting Latin American countries in the period 1999-2015.

\section{Empirical approach and results}

Central bank interventions in the foreign exchange market have been common in Latin America in recent years. However, as exchange rates may appreciate or depreciate in spite of central bank interventions, it is of interest to gauge the overall pressures on exchange rates by also considering the trends in foreign-exchange reserves and interest rates.

One way to combine these three elements (exchange rates, interest rates, and reserves) in a single index is to construct an exchange market pressure (EMP) index, as proposed by Kaminsky, Lizondo and Reinhart (1998) and by Reinhart and Kaminsky (1999). The index is calculated as follows:

4 "There is a fundamental asymmetry in the way macroeconomic policy deals with changes in the exchange rate in developing economies, especially in Latin America. Because appreciations are deflationary and depreciations are inflationary in the short run, any democratic government tends to tolerate appreciations but fight depreciations of their currencies. In fact, the adjusting period of the economy after a depreciation of its domestic currency may be longer than the mandate of elected officials, and this creates an asymmetric response of democratic governments to changes in the real exchange rate" (Barbosa-Filho, 2015).

5 "To the extent that the Central Bank reacts only to changes in the inflation rate it becomes very tempting for the monetary authority to subordinate the exchange rate to its inflation objectives or to respond in an asymmetrical way to appreciations and depreciations. There is consequently a 'fear to depreciate', more than a 'fear of floating'. This tends to make monetary policy pro-cyclical in the fact of external shocks. For example, in the face of a negative export demand shock, which tends to lower economic activity, the monetary authority tends to moderate the pressure towards depreciation through an increase in interest rates which aggravates the recession" (Ros, 2015). 


$$
E M P_{i t}=\frac{\Delta E_{i t}}{E_{i t}}-\frac{\sigma_{E}}{\sigma_{r}} \frac{\Delta r_{i t}}{r_{i t}}+\frac{\sigma_{E}}{\sigma_{I n t}} \Delta I n t_{i t}
$$

where $E M P_{i t}$ is the exchange market pressure index, $E_{i t}$ is the exchange rate, $r_{i t}$ denotes gross reserves, $I n t_{i t}$ is the monetary policy benchmark interest rate, $\Delta$ denotes change, and the variables $\sigma_{E}$, $\sigma_{r}$, and $\sigma_{I n t}$ are the standard deviations of the exchange rate, gross reserves and the monetary-policy rate, respectively. ${ }^{6}$ A positive EMP implies net pressure towards depreciation, while a negative EMP indicates net pressure for appreciation.

Figures 1 to 5 in the appendix track the EMP index for Brazil, Chile, Colombia, Mexico and Peru over the last 15 years. They also display the natural logarithm of the exchange rate, so the slope of the line captures the rate of depreciation. The figures clearly show that the inflation-targeting Latin American countries experienced significant pressures towards appreciation, but also important pressures for depreciation. The general trend was appreciation, which was only reversed recently by abrupt depreciations; but it is also clear that other factors, such as reserve accumulation, played a role in reversing exchange rate pressures, both upwards and downwards (also documented, for example, by Chang, 2008).

A more complete story is reported in table 1 , which displays summary statistics for the rate of devaluation, the change in the benchmark interest rate and the rate of growth of reserves (with monthly data) for the five countries over the period 1999-2015. The table reveals a number of interesting facts. For example, it shows that both Chile and Mexico have very volatile exchange rates (consistent with the casual observation that both countries have relatively flexible regimes); but, the exchange rate (and the interest rate) is less volatile in Peru, which has a highly dollarized financial system. It should be noted that the Central Bank of Peru applies several non-conventional monetary policy tools, such as reserve requirements on dollar-denominated assets. As expected, reserves display very little volatility in all five countries.

Table 1

Summary statistics

\begin{tabular}{lllcrrr}
\hline & & Brazil & Chile & Colombia & Mexico & Peru \\
\hline$\Delta \ln$ (Exch. rate) & Mean & 0.0034 & 0.0283 & 0.0078 & -0.0277 & -0.0088 \\
\cline { 2 - 6 } & Standard deviation & 0.0506 & 0.3692 & 0.0864 & 0.4186 & 0.1137 \\
\cline { 2 - 6 } & Maximum & 0.2532 & 5.0289 & 1.0787 & 0.1794 & 0.0486 \\
\cline { 2 - 6 } & Minimum & -0.1477 & -0.0699 & -0.1120 & -5.7083 & -1.5357 \\
\hline \multirow{2}{*}{ Interest rate } & Mean & -0.0254 & -0.0109 & -0.0241 & -0.0763 & 0.0035 \\
\cline { 2 - 6 } & Standard deviation & 0.5925 & 0.4088 & 0.3677 & 0.7462 & 0.2236 \\
\cline { 2 - 6 } & Maximum & 3.0000 & 3.0000 & 2.0000 & 2.7700 & 0.5000 \\
\cline { 2 - 6 }$\Delta$ In (Reserves) & Minimum & -2.5000 & -2.5000 & -2.000 & -3.4000 & -1.0000 \\
\cline { 2 - 6 } & Mean & 0.0127 & 0.0053 & 0.0094 & 0.0101 & 0.0101 \\
\cline { 2 - 6 } & Standard deviation & 0.0489 & 0.0375 & 0.0191 & 0.0272 & 0.0290 \\
\cline { 2 - 6 } & Maximum & 0.2445 & 0.1301 & 0.0838 & 0.1039 & 0.1043 \\
\cline { 2 - 6 } & Minimum & -0.3110 & -0.1646 & -0.0796 & -0.1641 & -0.1142 \\
\hline
\end{tabular}

Source: Prepared by the author on the basis of data from central banks.

Based on empirical observation and a preliminary reading of the data and, to judge from the mean rate of depreciation, there is no suggestion of bias towards either appreciation or depreciation. In fact, it could be argued that the central banks tried very hard to avoid appreciation, given their large purchases of foreign-exchange reserves.

6 The subscripts represent country " $i$ " in period " $t$ "; 24 -month rolling averages are used for the standard deviations. The data are monthly. 
Yet this casual observation is not enough to obtain a definitive picture. For instance, large reserve purchases may be driven by other motives, and not necessarily carried out during periods of appreciation. ${ }^{7}$ Moreover, as shown by Pontines and Siregar (2012), in East Asian countries that used inflation targeting, fear of appreciation was the rule. Despite tremendous pressures towards nominal appreciation, the central banks in those countries intervened more heavily when the exchange rate fell than when it rose.

Does a similar or opposite result hold for Latin American countries? This section follows the Pontines and Siregar approach, by estimating a set of nonlinear least-square models and a set of Markovswitching models to discover whether exchange-rate behaviour displayed any signs of asymmetry. The results are then expanded by asking whether the central bank was responsible for the observed developments, using generalized method of moments (GMM) reaction functions for monetary policy and reserve accumulation.

The sample for the nonlinear models is restricted to the period spanning 1999 to 2015 for Brazil, Chile, Colombia, Mexico, and Peru -the largest inflation-targeting countries in Latin America. But unlike Pontines and Siregar (2012), who use monthly and weekly data for nominal exchange rates, this paper uses daily data. ${ }^{8}$

\section{LSTR2 and Markov-switching models}

One way to analyse the behaviour of the exchange rate is through a smooth transition autoregressive (STAR) model ${ }^{9}$ of the following functional form:

$$
y_{t}=\alpha_{0}+\sum_{i=1}^{p} \alpha_{i} y_{i}+F\left[\beta_{0}+\sum_{i=1}^{p} \beta_{i} y_{i}\right]+\varepsilon_{t}
$$

where $\alpha_{0}$ is the intercept term; $\alpha_{i}$ (with $i=1, \ldots, p$ ) denotes the autoregressive parameters; $\beta_{0}$ is the nonlinear intercept and $\beta_{i}$ represents the nonlinear autoregressive parameters; $\varepsilon_{t}$ is the error term with the standard properties; and $F$ is the transition function that characterizes the smooth transition dynamics between two regimes.

The $F$ function can take different forms. The natural starting point when describing STAR models is the two-regime LSTR1 model with the following general logistic transition function, which takes values in the interval between zero and one:

$$
F=\frac{1}{1+e^{-\gamma\left(y_{t-d^{-}}\right)}}
$$

where $\gamma>0$ is the slope parameter (which measures the speed of transition between the two regimes); $c$ is the threshold parameter (which indicates the location of the transition) and $\gamma_{t-d}$ is the transition variable with the associated lag parameter $d .{ }^{10}$ It should be noted that the model is linear if $\gamma \rightarrow 0$, whereas if $\gamma \rightarrow \infty$ it becomes a two-regime model. In the intermediate case, the transition between the two regimes is "smooth" (hence the name of the model).

\footnotetext{
7 As will be seen in section III.B, in every case except Chile, changes in reserves are related to exchange-rate depreciations, but not to appreciations, despite the presence of an overall positive average rate of reserve accumulation.

8 The data come from the national central banks.

9 See Teräsvirta and Anderson (1992) and Van Dijk, Teräsvirta and Franses (2002), for a discussion of STAR models.

10 In this study, the transition variable is the lagged exchange rate variation.
} 
It turns out that a variant of the LSTR1 model is well suited for testing whether East Asian and Latin American central banks exhibit fear of appreciation-. In particular, the LSTR2 model proposed by Teräsvirta (1998) can be used:

$$
F=\frac{1}{1+e^{-\gamma\left(y_{t-d}-C_{L}\right)\left(y_{t-d}-C_{H}\right)}}
$$

The main difference is that LSTR2 involves two threshold parameters $C_{L}$ and $C_{H}$, for the lower and upper threshold, respectively, which capture the switching points between regimes. For example, an upper threshold of $6 \%$ and a lower threshold of $-2 \%$ means that there is a regime switch when the exchange rate moves up by $6 \%$ or down by $2 \%$, triggering a central bank reaction that tends to drive the exchange rate in the opposite direction, or keep it constant. The absolute value of these parameters can measure the monetary authorities' relative tolerance of exchange-rate variations, since they capture the pace at which exchange rates devalue as a result of central-bank intervention in the foreign exchange market (or a change in monetary policy). Pontines and Siregar (2012) estimate $C_{L}$ and $C_{H}$, and they find that $\left|C_{L}\right|<\left|C_{H}\right|$, thereby indicating that East Asian central banks are appreciation-averse.

Pontines and Siregar confirm their findings using a Markov-switching model to test whether the central banks are averse to currency appreciations based on whether the transition probability of remaining in the upper regime is greater than that of remaining in the lower regime. The following Markov-switching model is used in this study:

$$
y_{t}=\alpha_{0}(s)+\sum_{i=1}^{p} \alpha_{i} y_{i}(s)+\varepsilon_{t}(s)
$$

A Markov-switching model is an autoregressive model with a state variable $S$ that follows an irreducible ergodic two-regime Markov process with the following transition matrix $P$ :

$$
P=\left[\begin{array}{ll}
p_{11} & p_{12} \\
p_{21} & p_{22}
\end{array}\right]
$$

where the $p$ terms denote the transition probabilities. Thus, $p_{11}$ is the probability that the rate of change of the exchange rate remains in regime 1, given that it was in regime 1 in the previous period, while $p_{12}$ is the probability that rate of change of the exchange rate will move to the regime 2 , assuming it was in regime 1 in the previous period, and so on.

\section{Empirical results}

The estimation cycle for nonlinear models requires testing for nonlinearity and specifying the number of regimes and whether the transition function is exponential or logistic. But first, the lag order for the models must be selected. This is done using the standard Box-Jenkins methodology.

To select the lag length, the Akaike and Bayesian information criteria (AIC and BIC, respectively) are compared, and the model with the lowest AIC value is chosen. As argued by Teräsvirta, use of the Bayesian information criterion, which penalizes large models, often produces residuals with undesirable properties, such as persistent serial correlation, and incorrect acceptance of the nonlinear model, among other problems. Although this results in large autoregressive (AR) models, of between 7 and 19 lags, it is preferable to a bad model. The AIC criteria suggest an $A R(16)$ model for Brazil, an AR(7) for Chile, an AR(15) for Colombia, an AR(17) for Mexico and an $A R(19)$ for Peru. 
The correct STAR model can be determined by running a nonlinearity test. ${ }^{11}$ Alternatively, and in keeping with the literature, a specific model is implemented and later validated by the data (see Teräsvirta 1998). The present study adopts the former approach, ${ }^{12}$ and uses a three-regime logistic model since this is best suited to the needs of the study. As the lag decay length needs to be specified to estimate the model, the specification that maximizes the joint significance of all model parameters is chosen from among all possible lags, from 1 to a maximum of 12 .

Table 2 summarizes the results of the estimation of the LSTR2. The coefficients that are not shown are available on request. All the residuals pass the portmanteau test for white noise (using 4, 8 and 12 lags), except for Mexico. The residuals do not pass the heteroscedasticity test, but the estimation uses robust standard errors to correct for this.

Table 2

LSTR2 model

\begin{tabular}{|c|c|c|c|c|c|}
\hline & Brazil & Chile & Colombia & Mexico & Peru \\
\hline Lower threshold & $\begin{array}{r}-3.8055^{\star \star \star} \\
(0.0537)\end{array}$ & $\begin{array}{r}-0.3110^{\star \star \star} \\
(1.8550)\end{array}$ & $\begin{array}{r}-0.3459^{\star \star \star} \\
(0.0021)\end{array}$ & $\begin{array}{r}-2.2718^{\star \star \star} \\
(0.0026)\end{array}$ & $\begin{array}{r}-1.1031^{\star \star \star} \\
(0.0842)\end{array}$ \\
\hline Upper threshold & $\begin{array}{r}1.7507^{\star \star *} \\
(0.0873)\end{array}$ & $\begin{array}{r}0.3008^{\star \star *} \\
(0.0026)\end{array}$ & $\begin{array}{r}0.0255^{\star \star *} \\
(0.0017)\end{array}$ & $\begin{array}{r}1.8378 \\
(.)\end{array}$ & $\begin{array}{r}1.4677^{\star \star *} \\
(0.0986)\end{array}$ \\
\hline Speed of adjustment & $\begin{array}{r}4.3972 \\
(7.0863)\end{array}$ & $\begin{array}{l}7577.5060 \\
(80147.43)\end{array}$ & $\begin{array}{l}9327.3200 \\
(59160.59)\end{array}$ & $\begin{array}{r}86.6119 \\
(.)\end{array}$ & $\begin{array}{r}12.9158^{* *} \\
(6.0913)\end{array}$ \\
\hline Linear $\sigma^{2}$ & 0.4139 & 0.1802 & 0.1727 & 0.1364 & 0.0453 \\
\hline Nonlinear $\sigma^{2}$ & 0.3911 & 0.1780 & 0.1708 & 0.1220 & 0.0421 \\
\hline Ratio of $\sigma^{2}$ & 0.9451 & 0.9878 & 0.9888 & 0.8947 & 0.9299 \\
\hline Number of observations & 4436 & 4436 & 4436 & 4436 & 4436 \\
\hline R-squared & 0.3554 & 0.5013 & 0.7376 & 0.1848 & 0.5598 \\
\hline
\end{tabular}

Source: Prepared by the author, on the basis of data from central banks.

Note: Robust standard errors given in parentheses.

${ }^{\star \star \star} p<0.01 ;{ }^{\star \star} p<0.05 ;{ }^{*} p<0.1$.

The results show that the lower threshold is larger in absolute terms than the upper one for most countries, Peru being an exception. While the difference is very small for Chile and Colombia, it is large in the cases of Brazil and Mexico. In the case of Brazil, the upper threshold is $1.75 \%$ and the lower threshold is $-3.81 \%$; whereas in the case of Mexico the equivalent figures are $1.84 \%$ and $-2.27 \%$. It should be noted that the data represent daily rates of depreciation/appreciation, so they are in fact very large numbers.

Table 2 also reports the ratio of the variance of the residuals of the LSTR2 model to the variance of the residuals in the linear models. In all cases, the nonlinear residual variances are smaller, which supports the use of that model. Lastly, in general, all the thresholds are statistically significant, except for the lower threshold in the estimation for Mexico.

Table 3 shows the results of the estimation of the Markov-switching model. Once again, except in the case Mexico, all the residuals pass the portmanteau test for white noise (using 4, 8 and 12 lags), although they are heteroscedastic.

\footnotetext{
${ }^{11}$ To test for nonlinearity, a second-order approximation needs to be taken around $\gamma=0$ (that is, assuming a linear model). In a nutshell, this means estimating an autoregressive model of order $p$, with interaction terms that multiply each lag by the lag decay length (lag- $d$ ), then by lag- $d^{2}$, then by the lag- $d^{3}$ and then by the lag- $d^{4}$. Linearity means accepting the null hypothesis that all interaction terms are statistically equal to zero. An LSTR model is chosen if it is impossible to reject the null hypothesis that the terms multiplied by lag- $\mathrm{d}^{3}$ and lag- $\mathrm{d}^{4}$ are equal to zero, but the terms multiplied by lag- $d$ and lag- $\mathrm{d}^{2}$ are statistically significant. Lastly, for the null hypothesis that all the interaction terms are significantly different from zero, an LSTR2 model should be specified. To choose the lag- $d$ from among these models that pass the nonlinearity test, the one that displays the largest F-value is chosen. To that end, different $d$-values are chosen, from 1 to 12 , and the Lagrange multiplier test is run comparing a linear model with an LSTR model, and an LSTR model with an LSTR2 model.

12 The results (available on request) suggest that the LSTR2 model should be preferred for Brazil, Chile and Colombia, but not necessarily for Mexico and Peru.
} 
Table 3

Markov-switching model

\begin{tabular}{|c|c|c|c|c|c|}
\hline & Brazil & Chile & Colombia & Mexico & Peru \\
\hline \multicolumn{6}{|c|}{ Lower Regime } \\
\hline Transition probability & $\begin{array}{r}0.9733 \\
(0.0048)\end{array}$ & $\begin{array}{r}0.9696 \\
(0.0065)\end{array}$ & $\begin{array}{r}0.9552 \\
(0.0073)\end{array}$ & $\begin{array}{r}0.9846 \\
(0.0047)\end{array}$ & $\begin{array}{r}0.8832 \\
(0.0146)\end{array}$ \\
\hline Duration & $\begin{array}{l}37.4223 \\
(6.7705)\end{array}$ & $\begin{array}{l}32.9040 \\
(7.0379)\end{array}$ & $\begin{array}{l}22.3039 \\
(3.6313)\end{array}$ & $\begin{array}{r}64.9711 \\
(19.9761)\end{array}$ & $\begin{array}{r}8.5613 \\
(1.0669)\end{array}$ \\
\hline Variance & 0.3557 & 0.2575 & 0.2091 & 0.2545 & 0.8431 \\
\hline \multicolumn{6}{|c|}{ Upper Regime } \\
\hline Transition probability & $\begin{array}{r}0.8983 \\
(0.0222)\end{array}$ & $\begin{array}{r}0.9057 \\
(0.0264)\end{array}$ & $\begin{array}{r}0.8964 \\
(0.0167)\end{array}$ & $\begin{array}{r}0.9148 \\
(0.02019)\end{array}$ & $\begin{array}{r}0.8431 \\
(0.0235)\end{array}$ \\
\hline Duration & $\begin{array}{r}9.8320 \\
(2.1457)\end{array}$ & $\begin{array}{l}10.6001 \\
(2.9759)\end{array}$ & $\begin{array}{r}9.6509 \\
(1.5544)\end{array}$ & $\begin{array}{l}11.7398 \\
(3.0161)\end{array}$ & $\begin{array}{r}6.3752 \\
(0.9558)\end{array}$ \\
\hline Variance & 1.2112 & 0.7201 & 0.6836 & 0.7099 & 0.3128 \\
\hline Number of observations & 4436 & 4436 & 4436 & 4436 & 4436 \\
\hline
\end{tabular}

Source: Prepared by the author, on the basis of data from central banks.

Note: Robust standard errors given in parentheses.

The main interest for this study lies in the transition probabilities. Both the lower and upper regimes are very persistent; but, in general, the lower regime is more so, with the single exception of Peru. Brazil, Chile and Mexico display appreciations that last for very long periods of time (37, 33 and 64 days, respectively) - on average over three times longer than depreciations in Brazil and Chile, and more than six times longer in Mexico.

In the case of Colombia, while appreciations last longer than depreciations, the difference is smaller (22 days compared to 10). Lastly, in Peru, appreciations last only eight or nine days, while depreciations last for an average of six days. This result is interesting and consistent with the fact that the Peruvian economy is highly dollarized and its central bank is extremely averse to both appreciations and depreciations (Dancourt, 2015).

It is also worth noting that as a general rule, the variance of the rate of change of the exchange rate is some three to four times larger for depreciations than for appreciations, which suggests that appreciations represent a less turbulent scenario than depreciations. Here again, the variance of the rate of change of the log of the exchange rate is lower for Peru under both regimes.

To summarize, combining the results of the LSTR2 and the Markov-switching models, the overall picture is consistent with what observers report about inflation-targeting Latin American countries. In Brazil and Mexico, the de facto exchange-rate bands seem to be asymmetric, as discussed by Barbosa-Filho (2015) and Ros (2015). Interestingly, the upper threshold is larger than the lower for Peru, and the differences are small for Chile and Colombia.

In the period 1999-2015, appreciations lasted longer than depreciations. Once again, this is not true for Peru, which is only country where both appreciations and depreciations have been very short-lived and the variances are smaller under both regimes. This is consistent with Peru's history; its central bank has been extremely averse to exchange-rate volatility in either direction, to avoid macroeconomic instability associated with liability dollarization and balance-sheet effects.

\section{GMM reaction functions}

The previous subsection presented evidence of asymmetric exchange-rate behaviour, at least in the cases of Brazil and Mexico, with periods of appreciation seeming to last much longer than periods of depreciation. Is monetary or exchange-rate policy responsible for these outcomes? To answer this question, this section estimates the reaction functions for the five largest inflation-targeting Latin American 
countries, using the behaviour of interest rates and reserves to ascertain whether exchange-rate variations in either direction influence monetary and exchange-rate policies.

Although other policies could be responsible for the observed exchange-rate behaviour, they are much harder to test. For example, capital controls are an additional policy option, but they are difficult to adjust in the presence of short-term fluctuations. Moreover, there is not enough high-frequency data to run a reasonable test using capital controls.

Analysing variations in interest rates and reserves is both interesting and possible with the existing data. As will be shown below, signs of asymmetric interventions appear in the form of changes in reserves. Thus, Latin American central banks seek to combat excessive exchange-rate movements mainly by buying and selling reserves, while using the nominal interest rate to target domestic objectives.

The reaction functions are estimated using an instrumental-variables GMM approach, given the potential correlation between the error term and the independent variable. It is reasonable to assume that policy variables, such as the exchange rate, interest rates and reserves, depend on output and inflation; but they also exert a lagged feedback effect on them.

Instrument variables for GMM are selected from the observable information sets for the central bank. The instruments are the lags from 2 to 12 of all the dependent variables, plus the natural log of the United States federal funds interest rate. The Newey-West heteroscedasticity- and autocorrelation-consistent (HAC) covariance matrix is used to eliminate serial correlation in the error term. Data limitations mean that the samples do not always coincide. The sample includes data as follows, Brazil, April 2000 to July 2015; Chile, January 1999 to January 2014; Colombia, January 1999 to October 2005; Mexico, February 2009 to July 2015; and Peru, October 2004 to May 2014. The following two equations are estimated:

$$
\begin{gathered}
\Delta R A T E_{t}=\beta_{0}+\beta_{1} \Delta \pi_{t}+\beta_{2}\left(Y_{t}-\bar{Y}_{t}\right)+\beta_{3} A P P_{t}+\beta_{4} D E P_{t}+u_{t} \\
\Delta R E S_{t}=\beta_{0}+\beta_{1} \Delta \pi_{t}+\beta_{2}\left(Y_{t}-\bar{Y}_{t}\right)+\beta_{3} A P P_{t}+\beta_{4} D E P_{t}+u_{t}
\end{gathered}
$$

where the variables $\triangle R A T E$ and $\triangle R E S$ represent the variations in the interest rate and stock of (gross) foreign exchange reserves, respectively. $\Delta \pi$ denotes the increase in the rate of inflation, and $(Y-\bar{Y})$ is the output gap. $A P P$ and $D E P$ represent dummy variables that are, respectively, equal to the rate of appreciation when the exchange rate appreciates and zero otherwise, or equal to the rate of depreciation when the exchange rate depreciates and zero otherwise. ${ }^{13}$ For example, in a situation of depreciation, $D E P$ is equal to the rate of depreciation and $A P P$ is equal to zero. Similarly, when there is an appreciation, $D E P$ is equal to zero and $A P P$ is equal to the rate of appreciation. In both equations $u$ is the error term; and all variables are lagged by one period. ${ }^{14}$ The sign and the statistical significance of the $\beta_{3}$ and $\beta_{4}$ coefficients are the main focus of interest.

Tables 4 and 5 show the results. All the models pass the Hansen misspecification test (which means that the null hypothesis that all the models are correctly specified cannot be rejected). The results discussed below are robust to the use of multilateral exchange rates, with the sole exception of Peru (available on request). This is consistent with the nature of monetary and exchange-rate policies in a country that suffers from dollarization problems. Presumably the bilateral dollar exchange rate is more important than that of a currency basket comprising Peru's main trading partners.

\footnotetext{
${ }^{13}$ The output gap is defined as the deviation of monthly output from the HP trend; the inflation-gap is the difference between the annualized rate of $\mathrm{CPI}$ inflation and the target; and reserves are gross. The interest rates used are central bank short-term interest rates (which explains why the series is shorter for Mexico and Peru, since they did not target an interest rate until 2002-2003).

${ }^{14}$ The results hold if contemporaneous values are used and the first lag is added to the set of instruments.
} 
Table 4

GMM reaction functions (interest rate)

\begin{tabular}{|c|c|c|c|c|c|}
\hline $\begin{array}{l}\text { Dependent variable: } \\
\text { Ln (interest rate) }\end{array}$ & Brazil & Chile & Colombia & Mexico & Peru \\
\hline Constant & $\begin{array}{l}-0.0013 \\
(0.0043)\end{array}$ & $\begin{array}{l}-0.0065 \\
(0.0060) \\
\end{array}$ & $\begin{array}{r}-0.0116^{\star \star \star} \\
(0.0033)\end{array}$ & $\begin{array}{c}-0.0017^{\star} \\
(0.0010)\end{array}$ & $\begin{array}{l}0.0125^{\star \star} \\
(0.0042)\end{array}$ \\
\hline$\Delta$ Inflation [t-1] & $\begin{array}{r}0.2949^{* \star *} \\
(0.0403)\end{array}$ & $\begin{array}{r}0.1344^{* * *} \\
(0.0422) \\
\end{array}$ & $\begin{array}{r}0.1806^{\star \star \star} \\
(0.0391) \\
\end{array}$ & $\begin{array}{l}-0.0109 \\
(0.0092)\end{array}$ & $\begin{array}{r}0.0788^{* * \star} \\
(0.0227)\end{array}$ \\
\hline Output gap [t-1] & $\begin{array}{l}-0.0002 \\
(0.0008)\end{array}$ & $\begin{array}{r}0.0008 \\
(0.0010)\end{array}$ & $\begin{array}{l}0.0008^{\star *} \\
(0.0003)\end{array}$ & $\begin{array}{r}0.0019^{\star \star \star *} \\
(0.0007)\end{array}$ & $\begin{array}{r}0.0024^{\star \star *} \\
(0.0007)\end{array}$ \\
\hline Appreciation [t-1] & $\begin{array}{r}0.1774 \\
(0.1484) \\
\end{array}$ & $\begin{array}{r}0.3865 \\
(0.3256) \\
\end{array}$ & $\begin{array}{l}-0.2248 \\
(0.2249) \\
\end{array}$ & $\begin{array}{l}0.2531^{\star *} \\
(0.1050)\end{array}$ & $\begin{array}{r}0.4560 \\
(0.5695) \\
\end{array}$ \\
\hline Depreciation [t-1] & $\begin{array}{l}0.2243^{*} \\
(0.1153) \\
\end{array}$ & $\begin{array}{r}0.3894 \\
(0.2386) \\
\end{array}$ & $\begin{array}{r}0.1224 \\
(0.0969) \\
\end{array}$ & $\begin{array}{c}-0.1301^{*} \\
(0.0615)\end{array}$ & $\begin{array}{l}-0.3710 \\
(0.3010)\end{array}$ \\
\hline Number of observations & 183 & 147 & 82 & 78 & 103 \\
\hline Hansen J ( $p$-value) & 0.4992 & 0.2695 & 0.6542 & 0.8652 & 0.8202 \\
\hline
\end{tabular}

Source: Prepared by the author, on the basis of data from central banks.

Note: 2-12 lags for the dependent and the independent variable, plus the natural log of the federal funds rate. Robust standard errors given in parentheses. ${ }^{\star \star \star *} p<0.01 ;{ }^{* \star} p<0.05 ;{ }^{\star} p<0.1$

Table 5

GMM reaction functions (reserves)

\begin{tabular}{|c|c|c|c|c|c|}
\hline $\begin{array}{l}\text { Dependent variable: } \\
\Delta \ln \text { (Gross Reserves) }\end{array}$ & Brazil & Chile & Colombia & México & Peru \\
\hline Constant & $\begin{array}{r}0.0169^{\star \star \star} \\
(0.0040)\end{array}$ & $\begin{array}{r}0.0043 \\
(0.0044)\end{array}$ & $\begin{array}{r}0.0079^{\star \star \star} \\
(0.0017)\end{array}$ & $\begin{array}{r}0.0139^{\star \star \star} \\
(0.0017)\end{array}$ & $\begin{array}{r}0.0144^{\star \star \star} \\
(0.0017)\end{array}$ \\
\hline$\Delta$ Inflation [t-1] & $\begin{array}{l}-0.0631^{*} \\
(0.0034)\end{array}$ & $\begin{array}{l}-0.0040 \\
(0.0050)\end{array}$ & $\begin{array}{r}0.0235 \\
(0.0194) \\
\end{array}$ & $\begin{array}{r}-0.0166^{*} \\
(0.0090)\end{array}$ & $\begin{array}{r}-0.0097^{*} \\
(0.0054)\end{array}$ \\
\hline Output gap [t-1] & $\begin{array}{r}0.0011 \\
(0.0007)\end{array}$ & $\begin{array}{r}0.0017^{\star \star *} \\
(0.0005)\end{array}$ & $\begin{array}{r}0.0006^{\star \star \star} \\
(0.0002)\end{array}$ & $\begin{array}{r}0.0013^{\star * *} \\
(0.0003)\end{array}$ & $\begin{array}{l}0.007^{\star \star} \\
(0.0003)\end{array}$ \\
\hline Appreciation [t-1] & $\begin{array}{r}0.034 \\
(0.1337)\end{array}$ & $\begin{array}{r}0.0705 \\
(0.1750)\end{array}$ & $\begin{array}{l}-0.2189 \\
(0.1430)\end{array}$ & $\begin{array}{l}0.0914^{*} \\
(0.0502)\end{array}$ & $\begin{array}{r}0.0892 \\
(0.1440)\end{array}$ \\
\hline Depreciation [t-1] & $\begin{array}{r}-0.3200^{\star \star \star} \\
(0.0633)\end{array}$ & $\begin{array}{l}-0.0089 \\
(0.1716)\end{array}$ & $\begin{array}{r}-0.2303^{\star *} \\
(0.0665)\end{array}$ & $\begin{array}{r}-0.1707^{\star \star \star} \\
(0.0534)\end{array}$ & $\begin{array}{r}-0.5477^{\star \star \star} \\
(0.2045)\end{array}$ \\
\hline Number of observations & 183 & 147 & 82 & 78 & 103 \\
\hline Hansen J ( $p$-value) & 0.3554 & 0.5013 & 0.7376 & 0.1848 & 0.5598 \\
\hline
\end{tabular}

Source: Prepared by the author, on the basis of data from central banks.

Note: 2-12 lags for the dependent and the independent variable, plus the natural log of the federal funds rate. Robust standard errors given in parentheses. ${ }^{\star \star \star} p<0.01 ;{ }^{* \star} p<0.05 ;{ }^{*} p<0.1$.

Table 4 shows that exchange-rate movements are only significant in Brazil and Mexico. In the latter, the coefficients are statistically significant, but the signs are wrong (appreciations trigger a rise in the interest rate, while depreciations cause a fall); in Brazil, only depreciations affect interest rates. The broader picture is that interest rates usually do not react to exchange-rate changes.

Table 5 reveals a very different scenario. The constant term is highly significant and positive, consistent with the large accumulation of foreign exchange reserves. More important for the purposes of this study, depreciations seem to reduce reserve accumulation, and the results on this are significant everywhere except Chile. Peru, which has a highly dollarized economy, seems to be the most depreciation-averse country, closely followed by Brazil. Only in Mexico are appreciations significant, but the effect is small. This suggests that reserve accumulation was significantly affected by currency depreciations, but not by appreciations.

To summarize, the estimation of the reaction functions suggests that foreign-exchange-market interventions were focused mainly on preventing depreciations notwithstanding a constant trend of reserve accumulation. This behaviour seems to explain the asymmetric exchange-rate behaviour, in particular in Brazil and Mexico. Interestingly, the Chilean central bank does not seem concerned about the nature of the exchange-rate fluctuations. 


\section{Conclusions}

This paper has analysed the potential presence of asymmetries in exchange-rate behaviour for a group of Latin American countries that adopted inflation targeting. Using daily data spanning 1999-2015, an LSTR2 model was used to estimate the threshold for changes in the exchange rate, and evidence was found that the lower threshold is larger in absolute value than the upper one, in particular for Brazil and Mexico. A Markov-switching model was then implemented to show that appreciations usually last longer than depreciations, and they are less volatile. Interestingly, in Peru alone, appreciations and depreciations were both short-lived and of roughly equal duration. The variance of the rate of depreciation was also smaller under both regimes in that country, consistent with the dollarization problem that characterizes the Peruvian economy.

The results were then extended to analyse the role of policy. A set of GMM equations was used to estimate a reaction function for interest rates and reserve accumulation (using monthly data). The observed asymmetric behaviour of the exchange rate was found to be attributable to reserve accumulation, but not to interest-rate policies.

The fact that this result does not hold for Chile is consistent with other findings that identify this as the only Latin American country willing to tolerate larger fluctuations in the exchange rate in either direction. However, this does not hold for Mexico, the other economy in which the exchange rate seemed to be extremely flexible (see table 1). This points to the existence of "fear of floating" in inflation-targeting Latin American countries, possibly with just one standout exception: Chile. Moreover, this behaviour seems to be more pronounced for Brazil and Mexico, the main case studies. ${ }^{15}$ Lastly, Peru seems to be a special case: its dollarization problem means that exchange-rate fluctuations are tightly constrained in both directions (although the variation in reserves seems to be more sensitive to depreciations than to appreciations).

Lastly, there is no evidence that central banks combat appreciations more aggressively than depreciations. Thus, unlike the inflation-targeting East Asian countries that display "fear of appreciation", "fear of floating" does seem to be present in some Latin American countries.

\section{Bibliography}

Ball, L. (1999), "Policy rules for open economies”, Monetary Policy Rules, J. Taylor (ed.), Chicago, University of Chicago Press.

Barbosa-Filho, N. (2015), "Monetary policy with a volatile exchange rate: the case of Brazil since 1999", Comparative Economic Studies, vol. 57, No. 3, Palgrave Macmillan.

Bernanke, B. and F. Mishkin (1997), "Inflation targeting. A new framework for monetary policy?", Journal of Economic Perspectives, vol. 11, No. 2, Nashville, Tennessee, American Economic Association.

Blanchard, O. and J. Gali (2007), "Real wage rigidities and the new Keynesian model", Journal of Money, Credit, and Banking, vol. 39, No. s1, Blackwell Publishing.

Calvo, G. and C. Reinhart (2002), "Fear of floating", The Quarterly Journal of Economics, vol. 117, No. 2, Oxford, Oxford University Press.

Chang, R. (2008), "Inflation targeting, reserve accumulation, and exchange rate management in Latin America", Borradores de Economía, No. 487, Bogota, Bank of the Republic.

Dancourt, O. (2015), "Inflation targeting in Peru: the reasons for the success", Comparative Economic Studies, vol. 57, No. 3, Palgrave Macmillan.

Kaminsky, G., S. Lizondo and C. Reinhart (1998), "Leading indicators of currency crises", IMF Staff Papers, vol. 45, No. 1, Washington, D.C., International Monetary Fund (IMF).

\footnotetext{
${ }^{15}$ As far as the author is aware no one has made a similar claim for the three other countries in the sample.
} 
Levy-Yeyati, E. and F. Sturzenegger (2007), "Fear of appreciation", KSG Working Paper, No. 07-047, Cambridge, Massachusetts, Harvard Kennedy School.

Pontines, V. and R. Rajan (2011), "Foreign exchange market intervention and reserve accumulation in emerging Asia: is there evidence of fear of appreciation?", Economic Letters, vol. 111, No. 3, Amsterdam, Elsevier.

Pontines, V. and R. Siregar (2012), "Exchange rate asymmetry and flexible exchange rates under inflation targeting regimes: evidence from four East and Southeast Asian countries", Review of International Economics, vol. 20, No. 5, Wiley.

Reinhart, C. and G. Kaminsky (1999), "The twin crises: the causes of banking and balance-of- payments problems", American Economic Review, vol. 89, No. 3, Nashville, Tennessee, American Economic Association.

Ros, J. (2015), "Central bank policies in Mexico: targets, instruments, and performance", Comparative Economic Studies, vol. 57, No. 3, Palgrave Macmillan.

Terasvirta, T. (1998), "Modeling economic relationships with smooth transition regressions", Handbook of Applied Economic Statistics, A. Ullah and D. Giles (eds.), New York, Dekker.

Terasvirta, T. and H. Anderson (1992), "Characterizing nonlinearities in business cycles using smooth transition autoregressive models", Journal of Applied Econometrics, vol. 7, S1, Wiley.

Van Dijk, D., T. Terasvirta and P. Franses (2002), "Smooth transition autoregressive models. A survey of recent developments", Econometric Reviews, vol. 21, No. 1, Taylor \& Francis. 


\section{Annex A1}

Figure A1.1

Brazil: exchange market pressure (EMP) index and natural logarithm of the exchange rate

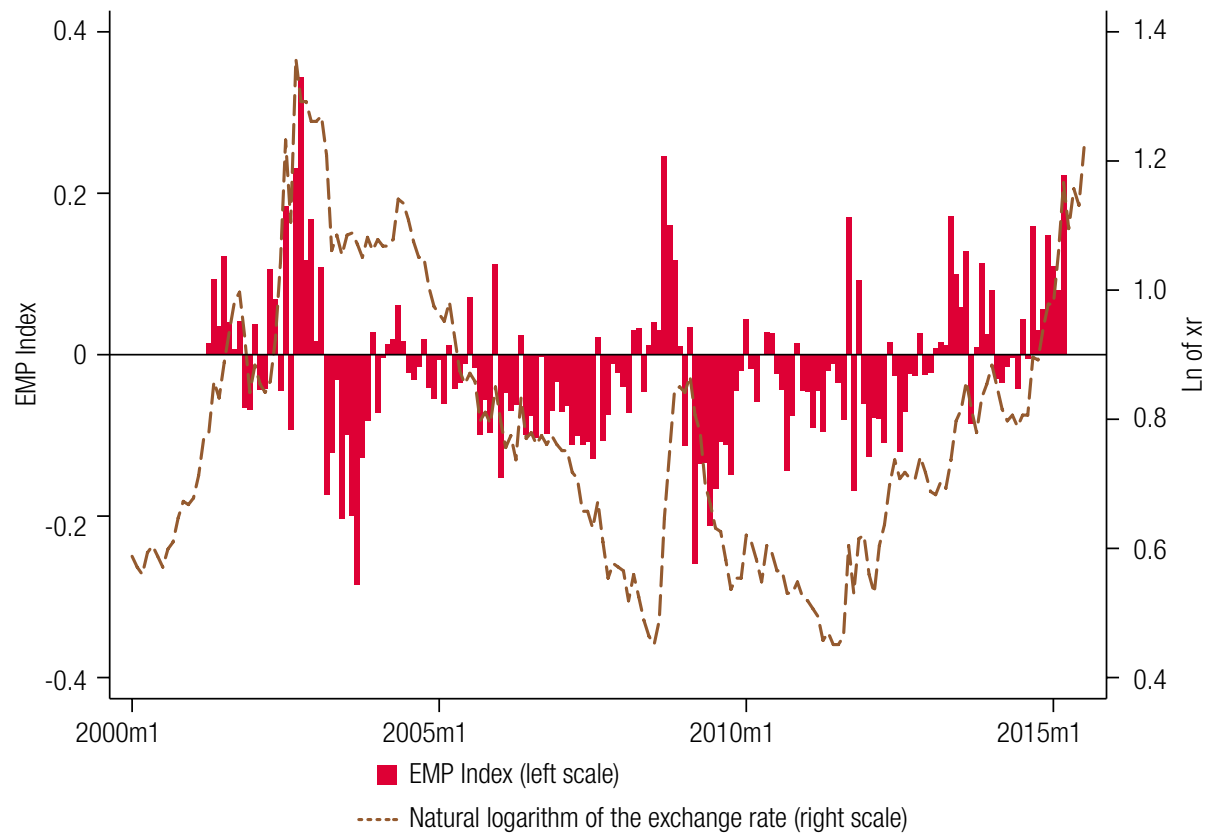

Source: Prepared by the author on the basis of data from central banks.

Figure A1.2

Chile: exchange market pressure (EMP) index and natural logarithm of the exchange rate



Source: Prepared by the author on the basis of data from central banks. 
Figure A1.3

Colombia: exchange market pressure (EMP) index and natural logarithm of the exchange rate

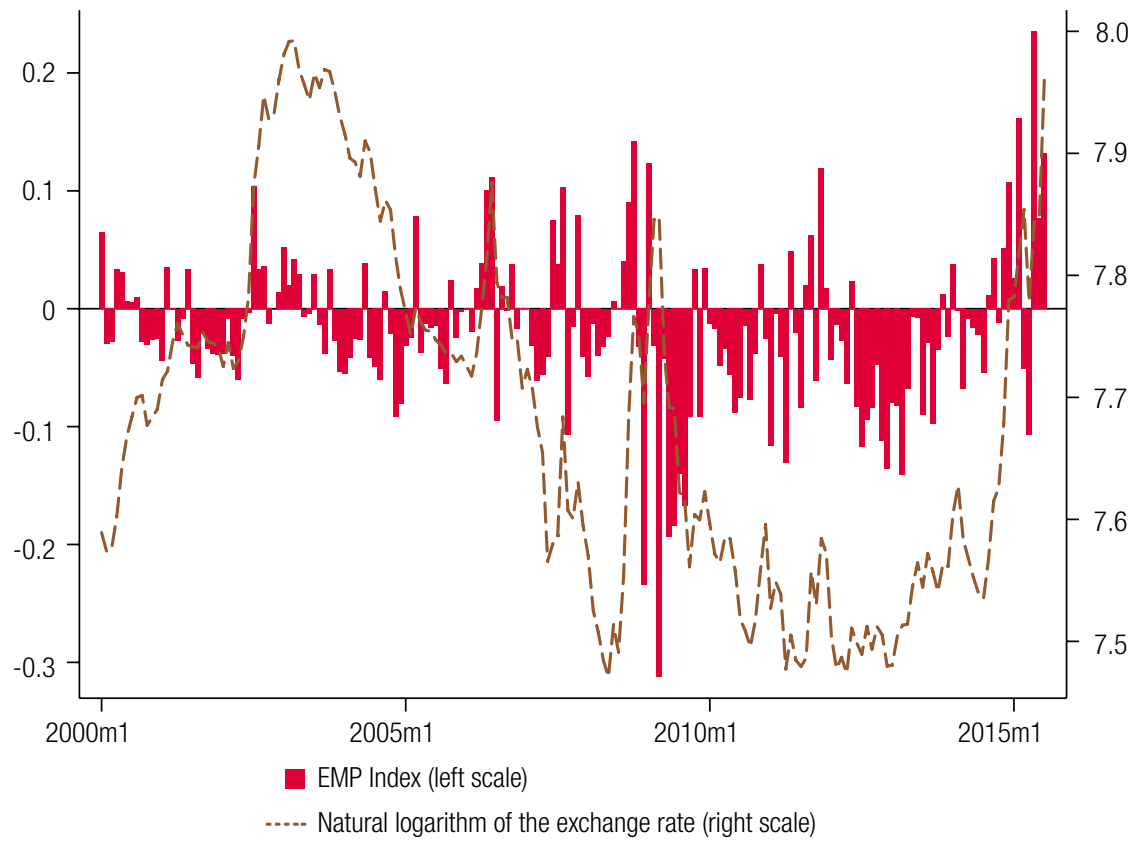

Source: Prepared by the author on the basis of data from central banks.

Figure A1.4

Mexico: exchange market pressure (EMP) index and natural logarithm of the exchange rate

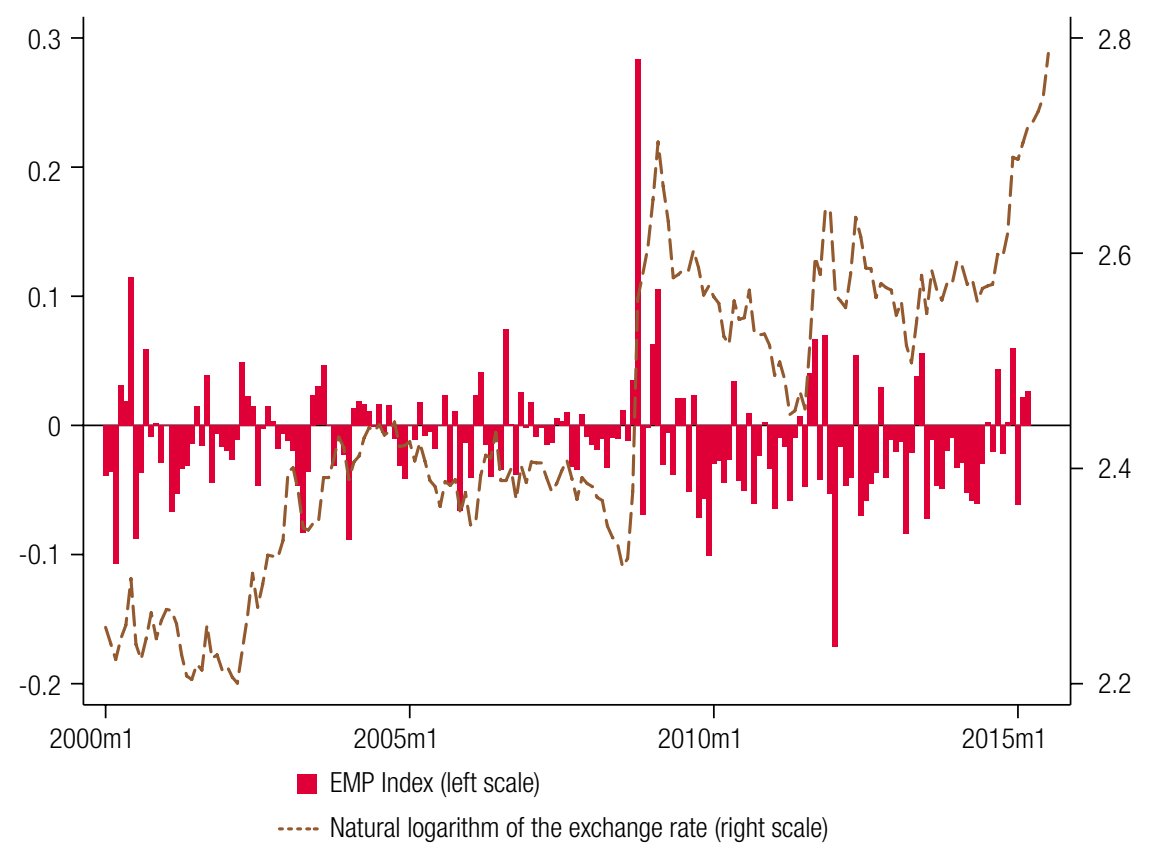

Source: Prepared by the author on the basis of data from central banks. 
Figure A1.5

Peru: exchange market pressure (EMP) index and natural logarithm of the exchange rate

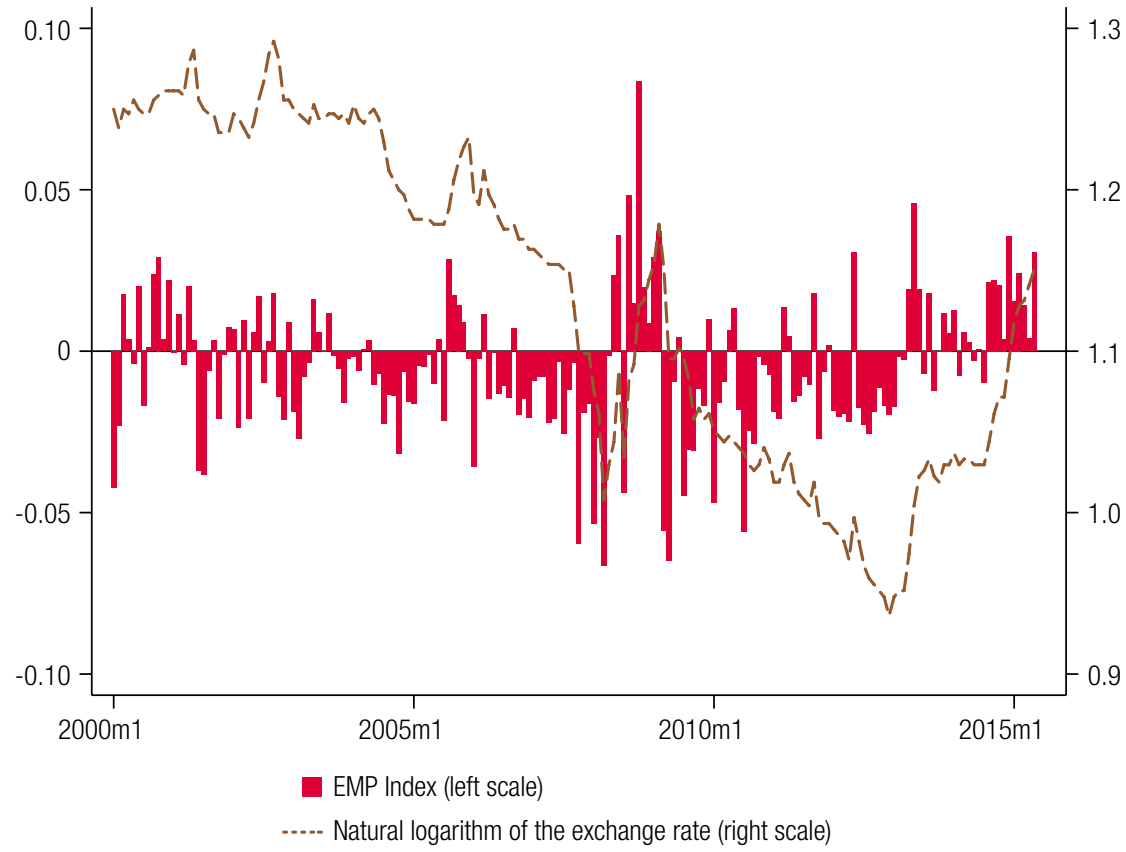

Source: Prepared by the author on the basis of data from central banks. 